ALCHEMY Jurnal Penelitian Kimia

Laman resmi: https://jurnal.uns.ac.id/alchemy

\title{
Senyawa Steroid dari Cocor Bebek (Kalanchoe tomentosa) sebagai Antibakteri Pseudomonas aeruginosa
}

\author{
Risyandi Anwar $^{a^{*},}$ Lilis Siti Aisyah ${ }^{\mathrm{b}}$, Faridia Puspita Lestari $^{\mathrm{b}}$, Delia Ilfani ${ }^{\mathrm{b}}$, Yenny Febriani Yun ${ }^{\mathrm{b}}$, Pebrian \\ Diki Prestya ${ }^{\mathrm{c}}$ \\ ${ }^{a}$ Departemen Ilmu Kedokteran Gigi Anak, FKG Universitas Muhammadiyah Semarang, Jawa Tengah \\ ${ }^{\mathrm{b}}$ Jurusan Kimia, FSI UNJANI, Cimahi \\ ${ }^{\mathrm{c}}$ Departemen Bedah Mulut, FKG Universitas Muhammadiyah Semarang, Jawa Tengah \\ "Corresponding author: drg.risyandi@unimus.ac.id \\ DOI: 10.20961/alchemy.17.2.51285.202-210
}

Received 18 May 2021, Accepted 22 August 2021, Published 09 September 2021

\section{Kata kunci: \\ $\beta$-sitosterol; bakteriostatik; bakterisid; Kalanchoe tomentos; plak.}

\begin{abstract}
ABSTRAK. Plak adalah pembentukan komunitas bakteri yang terorganisir pada permukaan gigi yang berupa lapisan tipis tidak berwarna. Pseudomonas aeruginosa adalah salah satu bakteri yang sangat berperan pada pembentukan plak. Metabolit sekunder yang terkandung dalam tanaman Kalanchoe tomentosa dapat digunakan sebagai antibakteri. Tahapan penelitian diawali dengan maserasi menggunakan pelarut $n$-heksan dan diklorometana. Ekstrak diklorometana dipisahkan menggunakan kromatografi cair vakum (KCV) dengan $n$-heksana dan etil asetat sebagai pelarut bergradien selanjutnya direkristalisasi dengan $n$-heksan, hasil rekristalisasi didapatkan isolat 1 . Isolat 1 dikarakterisasi dengan spektroskopi infrared (IR), ultraviolet (UV) dan nuclear magnetic resonance hydrogen $\left({ }^{1} \mathrm{H} \mathrm{NMR}\right)$ serta dibandingkan dengan literatur. Isolat 1 diketahui merupakan stigmast-5-en-3 $\beta$-ol atau $\beta$-sitosterol. Aktivitas antibakteri ekstrak diklorometana dan senyawa $\beta$-sitosterol kemudian ditentukan secara mikrodilusi. Ekstrak diklorometana dan senyawa $\beta$-sitosterol menunjukan sifat bakteriostatik dan bakterisid kuat terhadap bakteri Pseudomonas aeruginosa dengan nilai konsentrasi hambat minimum $(\mathrm{KHM})<10 \mu \mathrm{g} / \mathrm{mL}$.
\end{abstract}

ABSTRACT. Steroid Compounds from Cocor Bebek (Kalanchoe tomentosa) as Antibacterial Pseudomonas aeruginosa. Plaque is the formation of an organized bacterial community on the tooth surface in the form of a thin colorless layer. Pseudomonas aeruginosa is one of the bacteria that plays a very important role in plaque formation. Secondary metabolites contained in the Kalanchoe tomentosa plant can be used as antibacterial. The research phase begins with maceration using n-hexane and dichloromethane as solvents. The dichloromethane extract was separated using vacuum liquid chromatography $(\mathrm{KCV})$ with n-hexane and ethyl acetate as a gradient solvent then was recrystallized with $\mathrm{n}$-hexane; the result of recrystallization was obtained as isolate 1 . Isolate 1 was characterized by infrared (IR), ultraviolet (UV) and nuclear magnetic resonance hydrogen (1H-NMR) and was compared with the literature. Isolate 1 was known to be stigmast-5-en-3 $\beta$-ol or $\beta$-sitosterol. The antibacterial activity of the extract of dichloromethane and $\beta$-sitosterol compounds was determined by microdilution. The extracts of dichloromethane and $\beta$-sitosterol compounds showed bacteriostatic properties and strong bactericidal against Pseudomonas aeruginosa bacteria with a minimum inhibitory concentration (MIC) $<10 \mu \mathrm{g} / \mathrm{mL}$.

\section{PENDAHULUAN}

Prevalensi penyakit periodontal di dunia sekitar $20-50 \%$, dan setiap tahun terjadi peningkatan prevalensi yang terus menerus (Nazir et al., 2020). Prevalensi penyakit periodontal di Indonesia sebesar 74,1\%, sedangkan di wilayah Jawa Tengah penyakit periodontal memiliki prevalensi sebesar 25,8\% (Balitbang Kemenkes, 2018). Masalah tersebut terjadi karena kurang diperhatikannya kebersihan rongga mulut yang berakibat adanya penumpukan plak. Plak merupakan lapisan biofilm yang terdapat pada permukaan gigi (Marsh et al., 2015). Plak merupakan pembentukan komunitas bakteri yang terorganisir dan bekerja sama yang terhubung melalui aliran energi, nutrisi, dan jaringan metabolisme. Plak dapat ditemukan pada permukaan abiotik seperti gigi (Murakami et al., 2018). Pseudomonas aeruginosa merupakan salah satu bakteri yang sangat berperan dalam pembentukan plak gigi (Souto et al., 2018; Rivas et al., 2015).

Perluasan plak subgingiva ke dalam sulkus gingiva dapat mengganggu perlekatan bagian korona epitelium dari permukaan gigi sehingga tidak dapat dihilangkan dengan berkumur air saja. Beberapa cara pengendalian plak 
dilakukan dengan tujuan untuk mengeleminasi bertumpuknya plak pada permukaan gigi dan gusi (Van der Weijden et al., 2015). Menggosok gigi, penggunaan benang gigi, dan pengunaan pasta gigi merupakan beberapa upaya dalam mengeleminasi plak. Pencegahan penumpukan plak bisa dilakukan dengan obat kumur yang mengandung antibakteri (Figuero et al., 2017). Salah satu efek samping yang dapat terjadi karena banyaknya pemakaian obat kumur adalah adanya resistensi antibiotika (Cai et al., 2020; Parashar et al., 2015). Terjadinya resistensi bakteri terhadap antibiotik merupakan salah satu peluang besar untuk memanfaatkan kekayaan hayati penghasil senyawa bioaktif sebagai antibakteri (Lee et al., 2013). Dewasa ini penelitian dibidang Kesehatan khususnya bidang kedokteran dan kedokteran gigi banyak diarahkan pada pemanfaatan sumber daya alam. Hal ini dilakukan karena melimpahnya sumber daya alam yang dapat diperbaharui di bumi kita (Gyawali et al., 2014; Sakagami and Tomomura, 2018).

Indonesia merupakan salah satu negara yang mempunyai dua iklim, sehingga berbagai jenis tumbuhan dapat hidup dengan subur. Berbagai jenis tumbuhan tersebut diketahui memiliki khasiat menyembuhkan berbagai penyakit (Porras et al., 2021). Pemanfaatan berbagai tumbuhan sebagai pengobatan tradisional yang diturunkan dari nenek moyang telah dikenal oleh masyarakat Indonesia karena diyakini memiliki kemampuan menyembuhan terhadap suatu penyakit. Proses isolasi senyawa aktif maupun skrining bioaktivitas suatu tumbuhan merupakan salah satu upaya dalam memberdayakan keanekaragaman hayati yang dimiliki Indonesia sehingga dapat digunakan sebagai Pustaka ilmiah kimia (Susiarti et al., 2018). Diantara tanaman yang hidup subur di Indonesia dan memiliki khasiat sebagai obat tradisonal adalah tanaman Kalanchoe (Aisyah et al., 2016). Kalanchoe yang lebih dikenal dengan nama lokal "cocor bebek" atau "sosor bebek" merupakan genus terbesar pada famili Crassulaceae yang terdiri atas 125 spesies yang tersebar di daerah tropis dan subtropis. Tumbuhan genus Kalanchoe juga mempunyai nilai ekonomi dan merupakan tanaman yang banyak dimanfaatkan sebagai tanaman hias maupun sebagai penghasil produk sekunder untuk obat tradisional (Gao et al., 2011).

Beberapa penelitian melaporkan bahwa tanaman Kalanchoe mengandung senyawa metabolit sekunder seperti triterpenoid (Indriyanti and Garmana, 2011), bufadienolid (Czepas and Stocmal, 2017), flavonoid (Saleh et al., 2014), alkaloid (Paramita et al., 2018) dan steroid (Sylvia et al., 2020). Penelitian mengenai genus Kalanchoe dengan berbagai aktivitasnya telah banyak dilaporkan. Penelitian-penelitian tersebut diantaranya adalah Saleh (2014), yang memperoleh hasil pengujian aktivitas antioksidan pada berbagai ekstrak $K$. tomentosa yaitu ekstrak metilenklorida $\mathrm{IC}_{50} 71,3 \mu \mathrm{g} / \mathrm{mL}$, etil asetat $35,4 \mu \mathrm{g} / \mathrm{mL}$ dan $n$-butanol $99,3 \mu \mathrm{g} / \mathrm{mL}$. Penelitian yang lainya dilakukan dan memperoleh hasil ekstrak etil asetat $K$. tomentosa menunjukan adanya struktur flavonoid yang bisa meningkatkan aktivitas sitotoksik terhadap P-388 murine leukemia sel (Aisyah et al., 2016).

Berdasarkan penelusuran literatur penelitian mengenai $K$. tomentosa belum dilakukan, maka perlu dilakukan penelitian pada Kalanchoe spesies K. tomentosa untuk dapat dieksplorasi kandungan fitofarmakanya. Penelitian tersebut sangat perlu dilakukan mengingat bahwa $K$. tomentosa merupakan salah satu spesies Kalanchoe yang banyak tumbuh di Indonesia tetapi belum banyak dieksplorasi dalam hal identifikasi senyawa. Hal yang diungkap pada penelitian ini adalah jenis senyawa metabolit sekunder apa yang berhasil diisolasi dari ekstrak diklorometana $K$. tomentosa yang mempunyai aktivitas sebagai antibakteri $P$. aeruginosa yang merupakan bakteri yang ada pada plak gigi.

\section{METODE PENELITIAN}

Alat-alat yang digunakan dalam penelitian ini diantaranya seperangkat gelas laboratorium berbagai ukuran, alat-alat maserasi, alat-alat kromatografi cair vacum, blender untuk membuat simplisia, chamber, pipa kapiler, botol-botol vial berbagai ukuran, neraca timbang analitik, pinset, lampu Ultraviolet merk Vilber Lourmat VL8.LC, rotary evaporator merk Heidolph Laborota 4000, spektrofotometer Ultraviolet Hewlett Packard 8453, Spektrofotometer IR merk Shimadzu Tipe Prestige-21, Spektrofotometer Nuclear Magnetic Resonancy ${ }^{1} \mathrm{H}$ merk JEOL Tipe JNM-ECA $500 \mathrm{MHz}$, pelat mikro, vortex.

Bahan yang digunakan dalam penelitian ini adalah daun Kalanchoe tomentosa, akuadestilasi, $\mathrm{CH}_{3} \mathrm{COCH}_{3}$ (aseton), etil asetat $\left(\mathrm{CH}_{3} \mathrm{COOC}_{2} \mathrm{H}_{5}\right)$, diklorometana $\left(\mathrm{CH}_{2} \mathrm{Cl}_{2}\right)$, metanol $\left(\mathrm{CH}_{3} \mathrm{OH}\right)$, $n$-heksana $\left(\mathrm{C}_{6} \mathrm{H}_{14}\right)$, kloroform $\left(\mathrm{CHCl}_{3}\right)$ p.a, plat Kromatografi Lapis Tipis F254 Merck, silika gel Merck $60(0,2-0,5 \mathrm{~mm})$, silika gel Merck 60G, Nutrien Agar (NA), Nutrien Broth (NB).

\section{Ekstraksi}

Maserasi dimulai dengan dilarutkannya daun segar $K$. tomentosa sebanyak $20 \mathrm{~kg}$ dengan menggunakan pelarut $n$-heksana selama 24 jam. Proses maserasi dilanjutkan dengan cara diulang-ulang hingga filtrat tidak 
berwarna dengan pembuktian kontrol KLT. Tahap selanjutnya adalah tahap penyaringan, dilanjutkan melakukan ekstraksi residu hasil penyaringan dengan cara maserasi menggunakan metilen klorida selama 24 jam. Selanjutnya dilakukan penyaringan kembali, proses maserasi dilakukan berulang hingga filtrat tidak berwarna dengan pembuktian kontrol KLT. Selanjutnya dilakukan proses penyaringan kembali, filtrat cair ditampung dan dipekatkan menggunakan rotary evaporator untuk menghasilkan ekstrak metilen klorida yang berwarna hijau tua pekat (35 g), kemudian dilakukan uji antibakteri $P$. aeruginosa.

\section{Isolasi Ekstrak Diklorometana}

Proses isolasi dimulai setelah diketahui bahwa ekstrak diklorometana mempunyai sifat antibakteri $P$. aeruginosa. Ekstrak diklorometana dipisahkan secara kromatografi cair vakum (KCV) dengan silica gel G60 menggunakan gradient elusi $n$-heksan-EtOAc untuk menghasilkan 10 fraksi, pada fraksi 5 terdapat kristal jarum berwarna putih $(8 \mathrm{mg}$ ) yang kemudian dilakukan rekristalisasi dengan $n$-heksana untuk menghilangkan pengotor. Selanjutnya terhadap kristal berwarna putih tersebut dilakukan uji KLT untuk mengetahui kemurniannya dan kemudian dibandingkan dengan senyawa $\beta$-sitosterol murni.

\section{Pengujian Aktivitas Antibakteri}

Pada kolom kesatu sebanyak $100 \mu \mathrm{L}$ nutrien broth (NB) dimasukkan kedalam pelat mikro sebagai kontrol negatif. Suspensi mikro sebanyak $5 \mu \mathrm{L}$ ditambahkan ke dalam $10 \mathrm{~mL} \mathrm{NB}$ kemudian diaduk dengan alat vortex. Sebanyak $100 \mu \mathrm{L}$ campuran tersebut dimasukkan ke dalam pelat mikro pada kolom kedua sampai dua belas. Pada kolom kedua sampai dua belas, ditambahkan $100 \mu \mathrm{L}$ larutan ekstrak kemudian di homogenkan. Selanjutnya diambil $100 \mu \mathrm{L}$ dari kolom kedua kemudian dipindahkan ke kolom ketiga. Pengenceran terus dilakukan sampai pada kolom ke dua belas yang akan memiliki konsentrasi terkecil. Pelat diinkubasi pada suhu $37^{\circ} \mathrm{C}$ selama 24 jam kemudian amati bagian yang jernih. Konsentrasi terkecil dimana tidak ada pertumbuhan mikroba ditetapkan sebagai KHM. Sebanyak $5 \mu \mathrm{L}$ alikuot dari setiap bagian yang jernih dipindahkan ke dalam nutrien agar (NA) dan diinkubasi pada suhu $37^{\circ} \mathrm{C}$ selama 24 jam kemudian diamati. Konsentrasi terendah dimana tidak ada pertumbuhan mikroba ditetapkan sebagai konsentrasi bunuh minimal (KBM).

\section{HASIL DAN PEMBAHASAN}

\section{Ekstraksi dan Isolasi Senyawa}

Daun Kalanchoe tomentosa dihaluskan dengan tujuan untuk memperluas permukaan sampel. Permukaan sampel yang luas dapat mempermudah pelarut masuk ke dalam jaringan daun dalam mengekstrak senyawa yang terdapat di dalamnya sehingga menghasilkan ekstrak dengan rendemen yang besar. Isolasi $\beta$-sitosterol dilakukan dengan metode maserasi menggunakan pelarut metilen klorida menghasilkan ekstrak metilen klorida berwarna hijau tua pekat. Filtrat yang diperoleh dipekatkan dengan rotary evaporator, sehingga menghasilkan ekstrak pekat metilen klorida. Selanjutnya dilakukan uji antibakteri $P$. aeruginosa. Setelah diketahui bahwa ekstrak diklorometana mempunyai sifat antibakteri $P$. aeruginosa, sebanyak $35 \mathrm{~g}$ ekstrak diklorometana dengan eluen heksan-etil asetat secara gradien, 10 fraksi, pada fraksi ke 5 terdapat endapan berbentuk kristal berbentuk jarum berwarna putih. Spektrum UV menunjukkan adanya serapan kuat pada $\lambda_{\text {maks }} 264$ yang menunjukan adanya sistem alkena yang tidak terkonjugasi. Spektrum UV juga menunjukan adanya serapan lemah pada $364 \mathrm{~nm}$, hal ini menunjukkan tidak adanya sistem aromatik. Endapan fraksi 5 berupa serbuk putih berbentuk jarum, hasil KLT dibandingkan dengan stándar $\beta$-sitosterol menunjukkan kesamaan nilai Rf seperti pada Gambar 1. Endapan 5 dapat diprediksi sebagai $\beta$-sitosterol. 


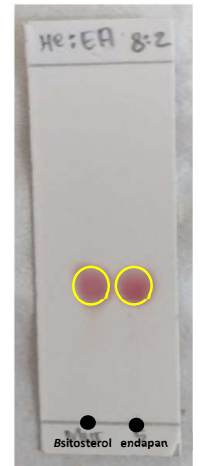

Gambar 1. Perbandingan $\beta$ sitosterol standar dengan endapan fraksi 5.

Hal ini diperkuat dengan data elusidasi struktur dengan menggunakan ${ }^{1} \mathrm{HNMR}$ (Gambar 2). Hasil analisis spektrum data ${ }^{1} \mathrm{HNMR}\left(500 \mathrm{MHz}, \mathrm{CDCl}_{3}\right)$ isolat 1 memperlihatkan sinyal karakteristik untuk senyawa steroid, di mana hanya terdapat satu sinyal $\delta_{\mathrm{H}} 5,35 \mathrm{ppm}$, dan terlihat sinyal yang menumpuk pada daerah antara $\delta_{\mathrm{H}} 1-2 \mathrm{ppm}$. Sinyal yang khas untuk proton olefinik diperoleh pada $\delta_{\mathrm{H}} 5$ ppm sedangkan sinyal proton teroksigenasi yang merupakan hal yang lazim ditemukan pada golongan senyawa steroid terdapat pada $\delta_{\mathrm{H}} 3 \mathrm{ppm}$ (Darwati et al., 2019). Karakteristik lainnya ditunjukan dengan adanya pergeseran kimia pada 1,42 ppm merupakan ciri khas proton dari gugus sikloheksana yaitu pada cincin A, cincin B dan cincin C pada senyawa steroid (Suryani et al., 2017).

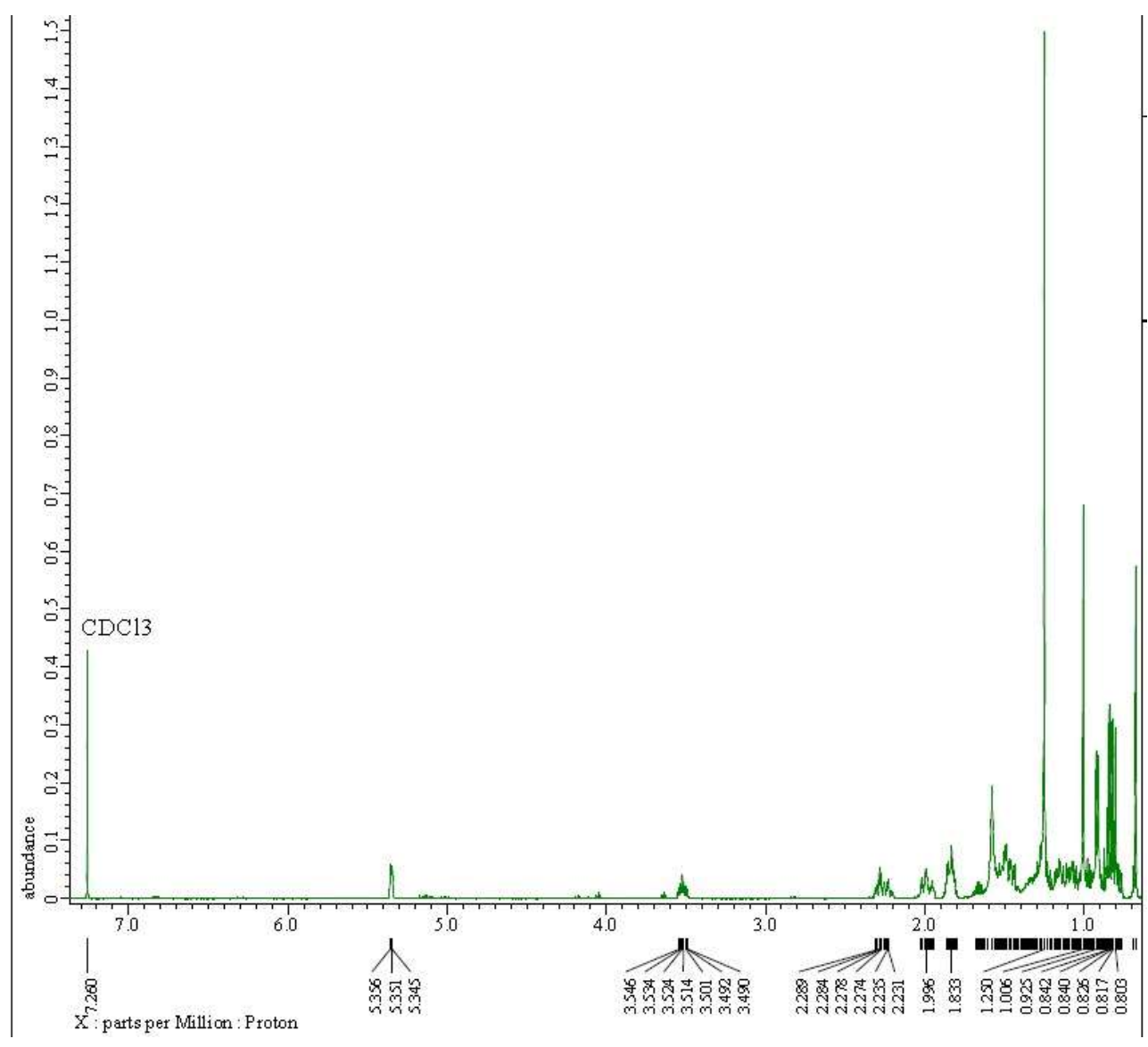

Gambar 2. Spektrum ${ }^{1} \mathrm{HNMR}$ Isolat 1. 
Tabel 1. Perbandingan data ${ }^{1}$ HNMR senyawa 1 dan $\beta$-sitosterol.

\begin{tabular}{|c|c|c|}
\hline \multirow{2}{*}{ Posisi atom $\mathrm{C}$} & Senyawa 1 & $\beta$-sitosterol* \\
\hline & \multicolumn{2}{|c|}{${ }^{1} \mathrm{HNMR} \delta \mathrm{H}(\mathrm{ppm})(\Sigma \mathrm{H}: \mathrm{mult}: \mathrm{J}=\mathrm{Hz})$} \\
\hline 1 & $0,82: 0,86(2 \mathrm{H}, d d, 10,5: 5,5)$ & $1,07: 1,02(2 \mathrm{H}, d d, 10,5: 5,5)$ \\
\hline 2 & $1,44: 1,47(2 \mathrm{H}, t d, 9,5: 6,0)$ & $1,44: 1,48(2 \mathrm{H}, t d, 9,5: 6,0)$ \\
\hline 3 & $3,49: 3,55(1 \mathrm{H}, m)$ & $3,51(1 \mathrm{H}, m)$ \\
\hline 4 & $2,23: 2.31(2 \mathrm{H}, m)$ & $2,22: 2,29(2 \mathrm{H}, m)$ \\
\hline 5 & - & - \\
\hline 6 & $5,35(1 \mathrm{H}, t, 2,5)$ & $5,35(1 \mathrm{H}, b r)$ \\
\hline 7 & $2,01(2 \mathrm{H}, d t, 5,6: 8,5)$ & $1,85: 2,01(2 \mathrm{H}, d t, 5,6: 8,5)$ \\
\hline 8 & $1,60(1 \mathrm{H}, m)$ & $1,57(1 \mathrm{H}, m)$ \\
\hline 9 & $0,93(1 \mathrm{H}, m)$ & $0,93(1 \mathrm{H}, m)$ \\
\hline 10 & - & - \\
\hline 11 & $1,42: 1,47(2 \mathrm{H}, m)$ & $1,42: 1,49(2 \mathrm{H}, m)$ \\
\hline 12 & $1,95(2 \mathrm{H}, d, 5,6)$ & $1,15: 1,98(2 \mathrm{H}, d, 5,6)$ \\
\hline 13 & - & - \\
\hline 14 & $1,01(1 \mathrm{H}, m)$ & $1,00(1 \mathrm{H}, m)$ \\
\hline 15 & $1,94: 2,03(2 \mathrm{H}, m)$ & $1,57(2 \mathrm{H}, m)$ \\
\hline 16 & $1,95(2 \mathrm{H}, m)$ & $1,84(2 \mathrm{H}, m)$ \\
\hline 17 & $1,09(1 \mathrm{H}, d t, 5,2: 8,5)$ & $1,09(1 \mathrm{H}, d t, 5,2: 8,5)$ \\
\hline 18 & $0,68(3 \mathrm{H}, s)$ & $0,68(3 \mathrm{H}, s)$ \\
\hline 19 & $1,01(3 \mathrm{H}, s)$ & $1,01(3 \mathrm{H}, s)$ \\
\hline 20 & $1,31(1 \mathrm{H}, m)$ & $1,36(1 \mathrm{H}, m)$ \\
\hline 21 & $0,69(3 \mathrm{H}, d: 6,1)$ & $0,92(3 \mathrm{H}, d, 6,1)$ \\
\hline 22 & $1,80(2 \mathrm{H}, m)$ & $1,38(2 \mathrm{H}, m)$ \\
\hline 23 & $1,50(2 \mathrm{H}, m)$ & $1,54(2 \mathrm{H}, m)$ \\
\hline 24 & $0,94: 0,98(1 \mathrm{H}, m)$ & $0,93(1 \mathrm{H}, m)$ \\
\hline 25 & $1,66(1 \mathrm{H}, m)$ & $1,66(1 \mathrm{H}, m)$ \\
\hline 26 & $0,84(3 \mathrm{H}, d, 6,2)$ & $0,84(3 \mathrm{H}, d, 6,2)$ \\
\hline 27 & $0,92(3 \mathrm{H}, d, 6,7)$ & $0,92(3 \mathrm{H}, d, 6,7)$ \\
\hline 28 & $1,25(2 \mathrm{H}, m)$ & $1,26(2 \mathrm{H}, m)$ \\
\hline 29 & $0,82(3 \mathrm{H}, s)$ & $0,83(3 \mathrm{H}, s)$ \\
\hline
\end{tabular}

Pada isolat 1 memperlihatkan adanya sinyal proton pada $\delta_{\mathrm{H}} 0,86(2 \mathrm{H}, d d) ; 1,44(2 \mathrm{H}, d t) ; 2,23(2 \mathrm{H}, m) ; 2,01$ $(2 \mathrm{H}, d t) ; 1,42(2 \mathrm{H}, m) ; 1,99(2 \mathrm{H}, d) ; 1,94(2 \mathrm{H}, m) ; 1,95(2 \mathrm{H}, m)$ masing-masing merupakan sinyal untuk proton metilen $\left(\mathrm{CH}_{2}\right)$. Sinyal proton pada $\delta_{\mathrm{H}} 3,49(1 \mathrm{H}, m) ; 5,35(1 \mathrm{H}, t) ; 1,60(1 \mathrm{H}, m) ; 0,93(1 \mathrm{H}, m) ; 1,01(1 \mathrm{H}, m) ; 1,09$ ppm $(1 \mathrm{H}, d t)$ masing-masing menunjukan sinyal untuk proton metin. Sinyal proton pada $\delta_{\mathrm{H}} 3,49(1 \mathrm{H}, m)$ menunjukan adanya hidrogen yang berdekatan pada gugus hidroksil yang diduga gugus hidroksil tersebut terdapat pada C-3 pada cincin A yang berada disebelah atas bidang molekul yakni pada pihak yang sama dengan gugusgugus metil pada C-10 dan C-13 yang disebut konfigurasi $\beta$. Sinyal pada $\delta_{\mathrm{H}} 5,35(1 \mathrm{H}, t)$ yang mengindikasikan adanya ikatan rangkap dua pada C-5 ditunjukan dengan adanya sinyal proton metin olefinik (Darwati et al., 2019). Sinyal proton pada $\delta_{\mathrm{H}} 0,68(3 \mathrm{H}, s)$ dan $1,01(3 \mathrm{H}, s)$ masing-masing merupakan gugus metil sebagai subtituen pada kerangka utama steroid yaitu pada C-10 dan C-13. Ketiga sinyal-sinyal tersebut (metilen, metin dan metil) mengindikasikan adanya kerangka steroid yang tersubtitusi oleh dua metil dan satu gugus hidroksil (Salempa et al., 2016). Pada daerah alifatik (subtituen pada C-17) terlihat pula beberapa sinyal yang mengindikasikan suatu unit alkana. Tiga sinyal untuk gugus metilen $\delta_{\mathrm{H}} 1,80(2 \mathrm{H}, m) ; 1,50(2 \mathrm{H}, m)$ dan $1,25(2 \mathrm{H}, m)$, tiga metin pada $\delta_{\mathrm{H}}$ $1,31(1 \mathrm{H}, m) ; 0,94(1 \mathrm{H}, m)$ dan $1,66(1 \mathrm{H}, m)$, empat gugus metil pada $\delta_{\mathrm{H}} 0,69(3 \mathrm{H}, d) ; 0,84(3 \mathrm{H}, d) ; 0,92(3 \mathrm{H}, d)$ dan $0,82(3 \mathrm{H}, d)$. Sepuluh sinyal proton ini merupakan kerangka alkil (Salempa et al., 2016). Pergeseran tersebut kemudian dibandingkan dengan senyawa $\beta$-sitosterol (Yun et al., 2017) dan memiliki banyak kesamaan. Maka dapat disimpulkan bahwa senyawa tersebut merupakan senyawa $\beta$-sitosterol. Perbandingan Data ${ }^{1}$ HNMR senyawa 1 dan $\beta$-sitosterol ditampilkan pada Tabel 1.

Hal tersebut diperkuat juga dengan spektrofotometri FTIR (Gambar 3) yang digunakan sebagai dasar untuk menafsirkan berbagai gugus fungsi yang terdapat pada senyawa sesuai dengan masing-masing gugus fungsi dan daerah spektrum serapan tersebut. Hasil dari identifikasi FTIR isolat 1 menunjukkan serapan pada daerah 3415 $\mathrm{cm}^{-1}$ menunjukkan intensitas melebar yang merupakan ciri khas serapan untuk gugus fungsi - $\mathrm{OH}$ (Okwu and Nnamdi, 2011). Hal ini diperkuat dengan adanya serapan pada $1047 \mathrm{~cm}^{-1}$ dengan intensitas tajam menunjukan 
serapan untuk gugus fungsi C-O alkohol. Serapan pada $2945 \mathrm{~cm}^{-1}$ dengan intensitas tajam menunjukkan serapan untuk gugus fungsi $-\mathrm{CH}$ alifatik, serapan pada $1649 \mathrm{~cm}^{-1}$ dengan intensitas melebar menunjukan serapan untuk gugus fungsi $\mathrm{C}=\mathrm{C}$. Hal ini diperkuat dengan adanya serapan pada $835 \mathrm{~cm}^{-1}$ dengan intensitas sedang menunjukan gugus fungsi alkena $=\mathrm{CH}$. Serapan pada $1649 \mathrm{~cm}^{-1}$ menunjukkan adanya rentangan $\mathrm{C}=\mathrm{C}$ nonkonjugasi yang memiliki kisaran panjang gelombang antara $1620-1680 \mathrm{~cm}^{-1}$ (Ahmed, 2017).

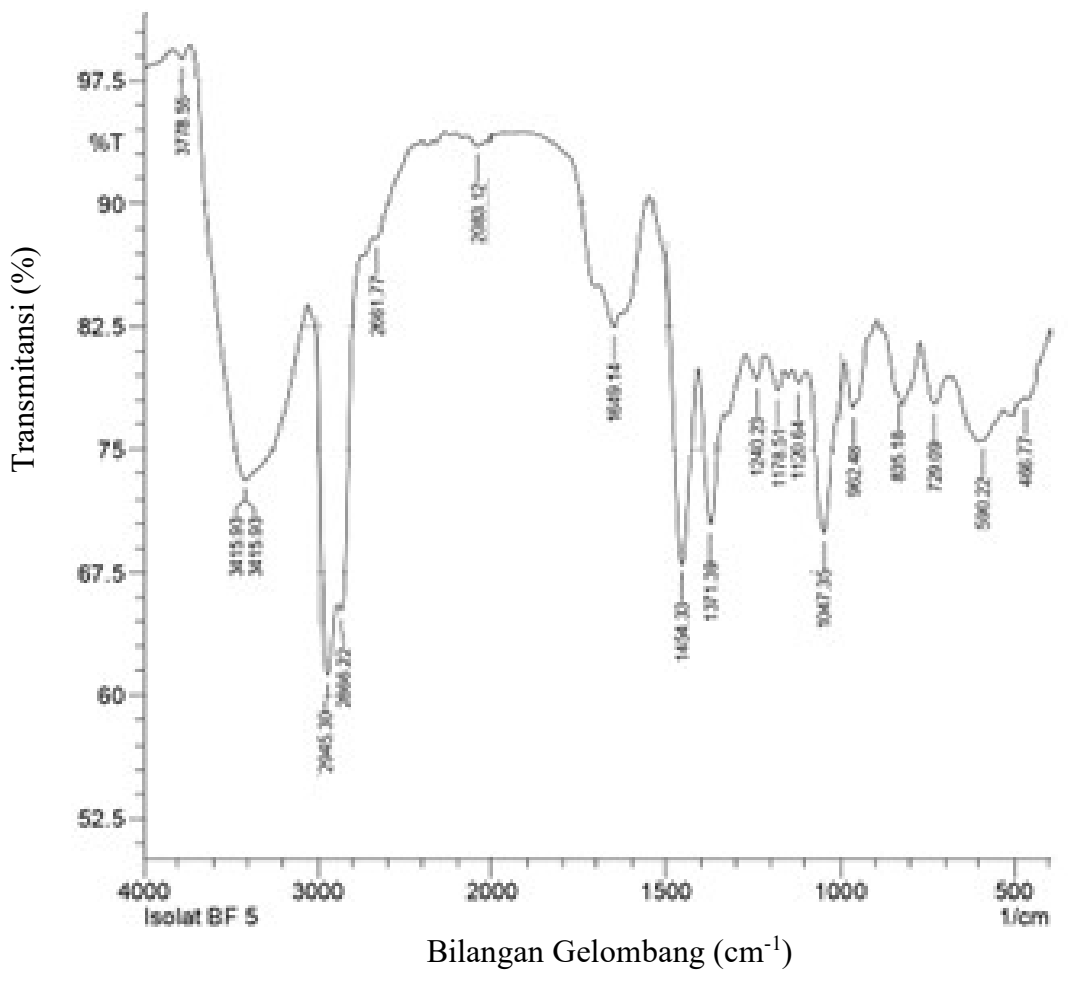

Gambar 3. Spektrum IR isolat 1.

Hal ini memperkuat bahwa isolat yang diperoleh merupakan golongan senyawa steroid yang tidak memiliki ikatan rangkap terkonjugasi. Pada serapan $1454 \mathrm{~cm}^{-1}$ dan $1371 \mathrm{~cm}^{-1}$ dengan intensitas tajam menunujukan serapan untuk gugus fungsi $\mathrm{C}-\mathrm{H}$ pada $\mathrm{CH}_{2}$ dan $\mathrm{CH}_{3}$. Berdasarkan hasil analisa inframerah isolat 1 dihasilkan serapan pada berbagai panjang gelombang, yang kemudian dibandingkan dengan serapan senyawa $\beta$-sitosterol murni penelitian Creswell et al. (1982) dan penelitian Fitriani (2013). Hasil perbandingan menunjukan serapan yang sama, hal ini dapat dilihat pada Tabel 2.

Tabel 2. Perbandingan data spektrum IR Isolat 1 dan $\beta$-sitosterol.

\begin{tabular}{llll}
\hline Isolat $\mathbf{1}\left(\mathbf{c m}^{-1}\right)$ & $\begin{array}{l}\boldsymbol{\beta} \text {-sitosterol } \\
\left(\mathbf{c m}^{-1}\right)\end{array}$ & $\begin{array}{l}\text { Pustaka***} \\
\left(\mathbf{c m}^{-1}\right)\end{array}$ & Gugus Fungsi \\
\hline 3415,93 & 3440,62 & $3450-3200$ & $\mathrm{O}-\mathrm{H}$ \\
2945,30 & 2936,69 & $2800-3000$ & $\mathrm{C}-\mathrm{H}$ alifatik \\
1649,14 & 1646,55 & $1680-1620$ & $\mathrm{C}=\mathrm{C}$ \\
1454,33 & 1463,42 & $1475-1300$ & $\mathrm{C}-\mathrm{H}$ (pada CH2) \\
1371,39 & 1381,65 & $1475-1300$ & $\mathrm{C}-\mathrm{H}$ (pada CH3) \\
1047,35 & 1053,89 & $1050-1260$ & $\mathrm{C}-\mathrm{O}$ alkohol \\
962,48 & 970,32 & $995-710$ & $=\mathrm{CH}$ alkena \\
\hline
\end{tabular}

**Creswell et al., 1982.

* Fitriani, 2013.

Berdasarkan data ${ }^{1} \mathrm{HNMR}$, hasil analisis spektrum FTIR dan KLT isolat 1 dengan pembanding $\beta$-sitosterol murni dapat disimpulkan bahwa isolat 1 hasil isolasi dari ekstrak diklorometana tanaman $K$. tomentosa diduga merupakan senyawa $\beta$-sitosterol yang mempunyai nama IUPAC stigmast-5-en-3 $\beta$-ol senyawa tersebut merupakan 
kelompok stigmastan dalam hidrokarbon induk steroid yang memiliki rumus molekul $\mathrm{C}_{29} \mathrm{H}_{50} \mathrm{O}$. Senyawa tersebut dapat dilihat seperti pada Gambar 4.

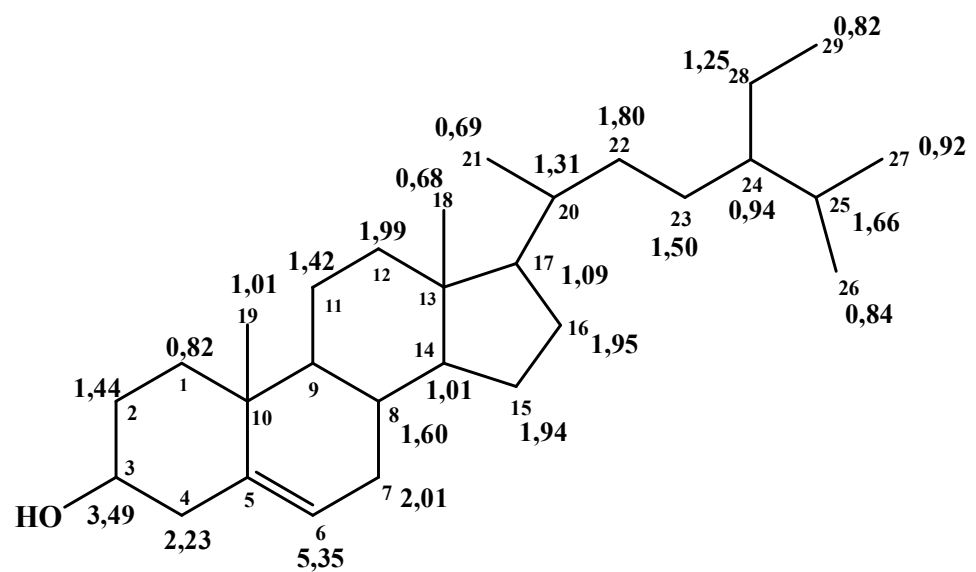

Gambar 4. Struktur stigmast-5-en-3 $\beta$-ol ( $\beta$-sitosterol).

\section{Pengujian Aktivitas Antibakteri}

Hasil pengujian aktivitas antibakteri ekstrak diklorometana Tabel 3 menunjukan bahwa ekstrak diklorometana bersifat bakteriostatik dan juga bakterisid terhadap bakteri $P$. aeruginosa dengan masing-masing nilai KHM sebesar 1,95 $\mu \mathrm{g} / \mathrm{mL}$ dan KBM 3,91 $\mu \mathrm{g} / \mathrm{mL}$. Berdasarkan literatur, nilai KHM dan KBM tersebut dapat dikatakan ekstrak diklorometana memiliki aktivitas kuat terhadap bakteri P. aeruginosa.

Tabel 3. Hasil uji antibakteri ekstrak diklorometana dan $\beta$-sitosterol.

\begin{tabular}{|l|l|l|l|}
\hline Sampel & Bakteri Uji & \multicolumn{2}{c}{ Hasil Uji } \\
\cline { 3 - 4 } & & KHM $(\boldsymbol{\mu g} / \mathbf{m L})$ & 3,91 \\
\hline Ekstrak diklorometana & P. aeruginosa & 1,95 & 7,81 \\
\hline Senyawa $\beta$-sitosterol & P. aeruginosa & 7,81 & \\
\hline
\end{tabular}

Hasil pengujian aktivitas antibakteri $\beta$-sitosterol terhadap bakteri $P$. aeruginosa pada Tabel 3. menunjukan nilai KHM sebesar 7,81 $\mu \mathrm{g} / \mathrm{mL}$ dan nilai $\mathrm{KBM} 7,81 \mu \mathrm{g} / \mathrm{mL}$. Berdasarkan literatur, nilai KHM dan KBM tersebut bersifat bakteriostatik maupun bakterisid sehingga dapat dikatakan bahwa $\beta$-sitosterol memiliki aktivitas yang kuat terhadap bakteri $P$. aeruginosa.

Hasil uji antibakteri tersebut di atas, memperlihatkan bahwa ekstrak diklorometana dan $\beta$-sitosterol memiliki potensi menghambat dan membunuh bakteri Gram negatif $P$. aeruginosa. Potensi tersebut diduga karena pada bakteri Gram negatif dinding selnya memiliki struktur peptidoglikan berlapis tunggal, bersifat nonpolar dan mengandungan senyawa lipid yang tinggi (Pelczar and Chan, 2008). Sifat dinding bakteri seperti tersebut yang menjadikan dinding sel P. aeruginosa akan lebih mudah ditembus oleh senyawa antibakteri yang bersifat nonpolar.

Apabila dikaitkan dengan struktur $\beta$-sitosterol, isolat tersebut memiliki satu gugus hidroksil -OH yang dapat menginaktifasi sistem enzim bakteri dan merusak membran sitoplasma yang menyebabkan bocornya metabolit penting. Gugus - $\mathrm{OH}$ yang sifatnya polar dapat menembus peptidoglikan yang bersifat polar, dan merusak dinding bakteri dengan memutuskan ikatan peptidoglikan sehingga lapisan sel tidak terbentuk secara utuh. Tempat kerja antibakteri ini adalah pada dinding sel bakteri yaitu lapisan peptidoglikan. Lapisan peptidoglikan sangat penting bagi bakteri gram negative, karena untuk mempertahankan kehidupan bakteri dari lingkungan yang hipotonik. Apabila terjadi kerusakan atau hilangnya lapisan ini maka akan menyebabkan hilangnya kekuatan dinding sel dan akan mengakibatkan kematian (Neu and Gootz, 2001).

\section{KESIMPULAN}

Hasil isolasi dari ekstrak diklorometana tanaman $K$. tomentosa diperoleh senyawa murni golongan steroid yaitu senyawa $\beta$-sitosterol dan senyawa $\beta$-sitosterol tersebut bersifat bakteriostatik dan bakterisid terhadap $P$. aeruginosa. 


\section{DAFTAR PUSTAKA}

Ahmed, B., 2017. Chemistry of Natural Products.

Aisyah, L.S., Yun, Y.F., Abdilla, A.A., Herlina, T., Julaeha, E., and Supratman, U., 2016. Flavonoid Compounds from the Leaves of Kalanchoe Tomentosa and Their Cytotoxic Activity Against P-388 Murine Leukemia Cell. 2016. Akta Kimindo 1(1), 1-4. doi: 10.20307/nps.2017.23.2.139.

Balitbang Kemenkes. 2018. Riset Kesehatan Dasar. Kemenkes. Jakarta.

Cai, H. Chen, J. Perera, N.K.P and Liang, X. 2020. Effects of Herbal Mouthwashes on Plaque and Inflammation Control for Patients with Gingivitis: A Systematic Review and Meta-Analysis of Randomised Controlled Trials. Evidence-Based Complementary and Alternative Medicine. Evidence-Based Complementary and Alternative Medicine 20, 1-16. doi: 10.1155/2020/2829854.

Creswell, C.J., and Runquist, O.A., 1982. Analisis Spektrum Senyawa Organik, Edisi kedua, Penerbit ITB, Bandung.

Czepas, J. K., and Stochmal, A., 2017. Bufadienolides of Kalanchoe species: An Overview of Chemical Structure, Biological Activity and Prospects for Pharmacological Use. Phytochemistry Review 16, 1155-1171. doi: 10.1007/s11101-017-9525-1

Darwati, D., Nurlelasari, N., and Mayanti, T., 2019. Isolasi Senyawa Steroid Dari Akar Tumbuhan Asam Kandis (Garcinia cowa Roxb. Ex Dc) Sebagai Obat Penurun Demam (Steroid Compounds from Root Plant of Acid (Garcinia cowa Roxb. Ex Dc) For Fever Relief). Jurnal Penelitian Hasil Hutan 37(1), 51-58.

Figuero, E.N., Obrega, D.F., Gargallo, M.M., Tenuta, L.M.A., Herrera, D., and Carvalho, J.C., 2017. Mechanical and Chemical Plaque Control in the Simultaneous Management of Gingivitis and Caries: A Systematic Review. Journal of Clinical Periodontology 44(18), 116-134. doi: 10.1111/jcpe.12674.

Fitriani, 2013. Isolasi dan Uji Aktivitas Senyawa $\beta$-sitosterol dari Kulit Batang Kleinhovia hospita Linn. Skripsi. Makassar: Universitas Negeri Makassar.

Gao, H., Popescu, R., Kopp, B., and Wang, Z. 2011. Bufadienolides and Their Antitumor Activity, Natural Product Report 28(5), 953-969. doi: 10.1039/c0np00032a.

Gyawali, R and Ibrahim, S.A., 2014. Natural Products as Antimicrobial Agents. Food Control 412-429. doi: 10.1016/j.foodcont.2014.05.047.

Indriyanti, N and Garmana, A.N., 2011. Ekstrak Daun Cocor Bebek (Kalanchoe pinnata) Untuk Terapi Preventif Lupus Mencit yang Diinduksi dengan 2,6,10,14 Tetramethylpentadecane. Journal of Tropical Pharmacy and Chemistry 1(3), 221-226. doi: 10.25026/jtpc.v1i3.32

Lee, C.R., Cho, I.H., Jeong, B.C., and Lee, S.H., 2013. Strategies to Minimize Antibiotic Resistance. International Journal Environment Reserach Public Health 10, 4274-4305. doi:10.3390/ijerph10094274.

Marsh, P.D., Head, D.A., and Devine, D.A., 2015. Dental Plaque as a Biofilm and a Microbial CommunityImplications for Treatment. Journal of Oral Biosciences 57(4), 185-191. doi: 10.1016/j.job.2015.08.002.

Murakami, S., Mealey, B.L., Mariotti, A., and Chapple, C.L., 2018. Dental Plaque-Induced Gingival Conditions. Journal of Clinical Periodontology 45(20),17-27. doi: 10.1111/jcpe.12937

Nazir, M., Al-Ansari, A., Al-Khalifa, K., Alhareky, M., Gaffar, B., and Almas, K., 2020. Global Prevalence of Periodontal Disease and Lack of Its Surveillance. Scientific World Journal 2020, 1-8. doi: $10.1155 / 2020 / 2146160$.

Neu, H.C., and Gootz T.D., 2001 Antimicrobial chemotherapy. Medmicro.

Okwu, D.E., dan Nnamdi, F.U., 2011. Two Novel Flavonoids from Bryophyllum pinnatum and Their Antimicrobial Activity. Journal Chemistry Pharmacy Research 3(2),1-10.

Paramita, H., Puspasari, T.L., Hidayat, Y., Meliansyah, R., Dono, D., Maharani, R., and Supratman, U., 2018. Bioactivity Formulation of Leaf Extract of Kalanchoe pinnata and Seed of Azadirachta indica Against Spodoptera. Jurnal Cropsaver 1(1): 20-26. doi: 10.24198/cs.v1i1.16995.

Parashar, A., 2015. Mouthwashes and Their Use in Different Oral Conditions. Scholar Journal of Dental Science 2(2B), 186-191.

Pelczar, M.J., and Chan, E.C.S., 2008. Dasar-Dasar Mikrobiologi Jilid I. Universitas Indonesia. Jakarta.

Porras, G., Chassagne, F., Lyles, J.T., Marquez, L., Dettweiler, M., Salam, A.M., Samarakoon, T., Shabih, S., Farrokhi, D.R., and Quave, C.L., 2021. Ethnobotany and the Role of Plant Natural Products in Antibiotic Drug Discovery. Chemistry Review 121 (6), 3495-3560. doi: 10.1021/acs.chemrev.0c00922.

Rivas, C. R., Le Gall. F., Revert, K., Rault, G., Virmaux, M., Gouriou, S., Héry-Arnaud, G., Barbier, G., Boisramé, S., 2015. Pseudomonas aeruginosa and Periodontal Pathogens in the Oral Cavity and Lungs of Cystic 
Fibrosis Patients: A Case-Control Study. Journal of Clinical Microbiology 53, 1898-1907. doi: 10.1128/JCM.00368-15.

Sakagami, H. and Tomomura, M., 2018. Dental Application of Natural Products. Medicines 5(21), 1-8. doi: 10.3390/medicines5010021.

Saleh, M. M., Ghoneim, M. M., Kottb, S. dan El-Hela, A., 2014. Biologically Active Secondary Metabolites from Kalanchoe tomentosa. Journal of Biomedical and Pharmaceutical Research 3(6), 136-140.

Salempa, P., Lestari, A., and Jusniar, J., 2016. Isolasi Dan Identifikasi Senyawa Metabolit Sekunder Ekstrak Kloroform Kulit Batang Sukun (Artocarpus altilis). Chemica: Jurnal Ilmiah Kimia dan Pendidikan Kimia. 17(1), 76-82.

Souto, R., Boghossian, C.M.S., and Colombo, A.V.P., 2014. Prevalence of Pseudomonas aeruginosa and Acinetobacter spp. in Subgingival Biofilm and Saliva of Subjects with Chronic Periodontal Infection. Brazilian Journal of Microbiology 45(2), 495-501. doi: 10.1590/S1517-83822014000200017.

Suryani, D.I., Zaharah, T.A and Rudiyansyah, 2017. Karakterisasi Senyawa Steroid dari Fraksi Diklorometana Ranting Durian Klawing (Durio graveolens Becc.) Jurnal Kimia Kartika 6(4), 45-48.

Susiarti, S., Rahayu, M., and Rugayah. 2018. Diversity of Indonesian Medicinal Plant in The lowland Forest, Bodogol and Its Surrounding of Mount Gede Pangrango National Park, West Java. IOP Conf. Series: Earth and Environmental Science 166. doi :10.1088/1755-1315/166/1/012021.

Sylvia, D., Fatimah, and Pratiwi, D., 2020. Comparison of Antioxidant Activity of Some Cocor Bebek Leaf Extract (Kalanchoe pinnata) Using the DPPH Method. Jurnal Ilmiah Farmako Bahari 11(1), 21-31.

Van der Weijden, F.A., Van der Sluijs, E., Ciancio, S.G. and Slot, G.E., 2015. Can Chemical Mouthwash Agents Achieve Plaque/ Gingivitis Control? Dental Clinical North America 59, 799-829. doi: 10.1016/j.cden.2015.06.002.

Yun, Y.F., Aisyah, L.S., Saputra, T.R., Hakim, A.R., Purbaya, S., Herlina, T., Julaeha, E., Zainuddin, A., and Supratman, U., 2017. Senyawa Fenolik dari Daun Tanaman Kalanchoe prolifera (Crassulaceae). Jurnal Kimia VALENSI: Jurnal Penelitian dan Pengembangan Ilmu Kimia 3(1), 27-34. doi: 10.15408/jkv.v0i0.5037. 